\title{
Human neutrophils produce interferon gamma upon stimulation by interleukin-12
}

\author{
Frédéric Ethuin ${ }^{1,2}$, Bénédicte Gérard ${ }^{3}$, Jamel E Benna ${ }^{1}$, Anne Boutten ${ }^{4}$, \\ Marie-Anne Gougereot-Pocidalo ${ }^{1}$, Laurent Jacob ${ }^{2}$ and Sylvie Chollet-Martin ${ }^{1}$ \\ ${ }^{1}$ Laboratoire d'Immunologie et Unité INSERM 479, Hôpital Bichat, Paris, France; ${ }^{2}$ Département d'Anesthésie- \\ Réanimation, Hôpital Saint-Louis, Paris, France; ${ }^{3}$ Service de Biochimie Hormonale et Génétique, Hôpital \\ Bichat, Paris, France and ${ }^{4}$ Service de Biochimie A et Unité INSERM 408, Hôpital Bichat, Paris, France
}

\begin{abstract}
Interferon $\gamma($ IFN $\gamma)$ is a Th1 cytokine mainly produced by T cells, NK cells and macrophages in response to interleukin (IL)-12. As polymorphonuclear neutrophils (PMN) have been shown to produce and to release numerous cytokines, in particular upon IL-12 stimulation, we investigated the ability of highly purified PMN to secrete IFN $\gamma$. We found that PMN contained a small store of IFN $\gamma$, and that this store was rapidly secreted upon stimulation by degranulating agents such as formyl peptides. Moreover, after a few hours of stimulation with appropriate agents, PMN synthesized IFN $\gamma$. The effect of IL-12 was time- and concentration-dependent, and IL-12 combinations with IL-2, IL-15, IL-18 or LPS were highly synergistic. Cycloheximide inhibited IFN $\gamma$ release in such optimal conditions, confirming the ability of PMN to synthesize IFN $\gamma$. IFN $\gamma$ synthesis was associated with an increase in specific mRNA content, pointing to a transcriptional mechanism. The IFN $\gamma$ produced by PMN was biologically active, as demonstrated by its ability to induce TNF $\alpha$ synthesis by PMN themselves or to induce IL-10 synthesis by peripheral blood mononuclear cells. These findings reveal a novel pathway of autocrine and paracrine PMN activation. They also identified a new role for IF $\mathrm{N}$, bridging innate and adaptive immune responses.
\end{abstract}

Laboratory Investigation (2004) 84, 1363-1371, advance online publication, 28 June 2004; doi:10.1038/labinvest.3700148

Keywords: cytokines; interferon; interleukin; phagocyte

During the last decade, numerous studies have evidenced that polymorphonuclear neutrophils (PMN) can release a wide array of cytokines bringing about the definition of new roles of PMN in pathophysiology. PMN are major cytokine sources in humans. ${ }^{1,2}$ Through a variety of mechanisms, PMN are able to release granular stores of preformed cytokines such as oncostatin M (OSM) and hepatocyte growth factor (HGF) ${ }^{3,4}$ and to synthesize de novo other cytokines such as interleukin (IL)-8, IL12, tumor necrosis factor (TNF) $\alpha$ and IL-1 receptor antagonist (IL-1RA). ${ }^{1}$ Thus, in addition to their phagocytic and killer functions, PMN can participate in anti-inflammatory responses via IL-RA, angiogenesis and tissue repair via HGF and vascular endothelial growth factor (VEGF) ${ }^{1,5}$ B-cell homeostasis via BLys, ${ }^{6}$ and Th2 pathway regulation via IL- $4 .^{7}$ Relatively little information is available on

Correspondence: Dr S Chollet-Martin, PhD, Laboratoire d'Immunologie et Unité INSERM 479, Hôpital Bichat, 46 rue Henri Huchard, 75018 Paris, France.

E-mail: sylvie.martin@bch.ap-hop-paris.fr

Received 22 January 2004; revised 6 May 2004; accepted 10 May 2004; published online 28 June 2004
PMN secretion of Th1 cytokines. Here, we investigated whether PMN can synthesize and release interferon $\gamma$ (IFN $\gamma)$.

IFN $\gamma$ is the principal cytokine produced during Th1-type immune responses, in response to IL-12. The cells involved in IFN $\gamma$ production include NK cells, ${ }^{8} \mathrm{~T}$ cells, ${ }^{9}$ macrophages, ${ }^{10} \mathrm{~B}$ cells ${ }^{11}$ and eosinophils. ${ }^{12}$ It has also been suggested that PMN may synthesize IFN $\gamma$. Indeed, IFN $\gamma$-positive PMN have been observed in human endometrium, ${ }^{13}$ and also in lung and spleen tissue of two different murine models of infection. ${ }^{14,15}$ Yeaman et $a l^{13}$ found that isolated PMN released IFN $\gamma$ after IL-12+TNF $\alpha$ stimulation in vitro, while other investigators failed to detect IFN $\gamma$ after lipopolysaccharide (LPS) stimulation. ${ }^{13}$

We have previously obtained some evidence that IL-12-induced IL-8 production by PMN is dependent on endogenously produced IFN $\gamma \cdot{ }^{16}$ Here, we examined whether PMN contain preformed stores of IFN $\gamma$, and whether they are able to synthesize IFN $\gamma$ de novo. We found that highly purified PMN contain a small preformed stock of IFN $\gamma$, and that they can also synthesize and release bioactive IFN $\gamma$ after stimulation with IL-12 alone or, in a highly 
synergistic manner, in combination with LPS, IL-12, IL-15 or IL-18. This de novo synthesis appears to be regulated at least in part by a transcriptional mechanism. These data point to the existence of a new autocrine regulation loop in PMN, involving IL-12 and IFN $\gamma$, suggesting that PMN can influence the immune response towards a Th1 phenotype.

\section{Materials and methods}

\section{Isolation and Purification of Human Blood PMN}

PMN were purified from venous blood of healthy volunteers using a three-step procedure developed in our laboratory. ${ }^{4,5,16-18}$ Briefly, leukocytes were isolated in endotoxin-free conditions by sedimentation on a separating medium containing 9\% Dextran T-500 ${ }^{\circledR}$ (Pharmacia, Uppsala, Sweden) and 38\% Radioselectan ${ }^{\circledR}$ (Schering, Lys-lez-Lannoy, France). After red cell sedimentation, the leukocyte-rich suspension was centrifuged on a Ficoll-Paque ${ }^{\mathbb{B}}$ density gradient (Sigma, St Louis, MO, USA). Contaminating erythrocytes were removed by hypotonic lysis. To further purify PMN, monocytes, B lymphocytes and activated $\mathrm{T}$ lymphocytes were removed by 30-min incubation with pan-antihuman HLA class II-coated magnetic beads (Dynabeads M-450, Dynal AS, Oslo, Norway). As previously described, ${ }^{4}$ CD3 + and CD19+ cells were undetectable by flow cytometry (FACScan, Becton-Dickinson, San Jose, CA, USA); we also showed the absence of CD56 + cells, confirming the recovery of highly purified PMN free of NK cells and T lymphocytes.

\section{PMN Culture}

Purified PMN were resuspended in RPMI 1640 culture medium (Bio Whittaker, Gagny, France) supplemented with $10 \%$ heat-inactivated fetal calf serum (FCS, Bio Whittacker), L-glutamine $(2 \mathrm{mmol} /$ $\mathrm{ml})$, penicillin $(100 \mathrm{IU} / \mathrm{ml})$ and streptomycin (100 $\mu \mathrm{g} / \mathrm{ml})$, and $2 \times 10^{6} \mathrm{cells} / \mathrm{ml}$ were cultured for up to $48 \mathrm{~h}$ at $37^{\circ} \mathrm{C}$ with $5 \% \mathrm{CO}_{2}$ and increasing concentrations of IL-12 (1-100 ng/ml, R\&D Systems Abingdon-Oxon, UK) alone or combined with $100 \mathrm{ng} / \mathrm{ml}$ LPS derived from Escherichia coli (055:B5, Sigma, St Louis, MO, USA). The effect of IL-12 $(10 \mathrm{ng} / \mathrm{ml})$ was compared with that of other stimulating agents, including IL-2 $(10 \mathrm{ng} / \mathrm{ml})$, IL-15 (20 ng/ml), IL-18 (20 ng/ml), GM-CSF ( $5 \mathrm{ng} / \mathrm{ml})$ and $\mathrm{TNF} \alpha(10 \mathrm{ng} / \mathrm{ml})$ (R\&D Systems), alone or combined, in the presence or absence of LPS $(100 \mathrm{ng} / \mathrm{ml})$. In some experiments, PMN were preincubated with $1 \mu \mathrm{g} / \mathrm{ml}$ cycloheximide (CHX, Sigma) for $30 \mathrm{~min}$ at $37^{\circ} \mathrm{C}$ and then incubated with LPS $(100 \mathrm{ng} / \mathrm{ml})$ in the presence of IL-12 $(10 \mathrm{ng} / \mathrm{ml})$ and IL-15 $(20 \mathrm{ng} / \mathrm{ml})$ for $24 \mathrm{~h}$ at $37^{\circ} \mathrm{C}$. At the end of the culture period, cellfree supernatants were stored at $-70^{\circ} \mathrm{C}$ until IFN $\gamma$ assay. Cell viability was confirmed by trypan blue exclusion as previously described. ${ }^{5}$

\section{Enzyme-Linked Immunospot (ELISpot) Assay}

ELISpot assay (R\&D) was used to confirm the ability of PMN to produce IFN $\gamma$. We adapted the method recently described by Chen et al, ${ }^{19}$ allowing the visualization of IFN $\gamma$-secreting cells. Briefly, highly purified PMN $\left(5 \times 10^{6} / \mathrm{ml}\right)$ were cultured for $24 \mathrm{~h}$ in microplates coated with a monoclonal capture antibody specific for human IFN $\gamma$. Autologous peripheral blood mononuclear cells (PBMC) $\left(0.5 \times 10^{6} /\right.$ $\mathrm{ml}$ ) obtained by Ficoll-Paque ${ }^{\circledR}$ density-gradient separation served as positive controls. Both cell preparations (PMN and PBMC) were stimulated as described above, with LPS, IL-12, IL-2, IL-15 and IL-18, alone or in combination. During incubation, IFN $\gamma$ released by individual cells binds to the coating antibody. The plates are then washed and incubated at $4^{\circ} \mathrm{C}$ overnight with a biotinylated polyclonal antibody specific for human IFN $\gamma$. After washing, alkaline phosphatase-conjugated streptavidin is added for $2 \mathrm{~h}$ at room temperature before adding the substrate solution (BCIP/NBT). Blueblack spots of precipitate, representing individual IFN $\gamma$-secreting cells, are counted using an inverted microscope. All experiments were performed in triplicate.

\section{Degranulation Experiments}

Purified PMN $\left(10^{7} / \mathrm{ml}\right)$ were resuspended in Hanks' balanced salt solution (HBSS with $\mathrm{Ca}^{2+} / \mathrm{Mg}^{2+}$; Life Technologies, Cergy-Pontoise, France). Part of the cell suspension (unstimulated control PMN) was immediately centrifuged for $10 \mathrm{~min}$ at $4^{\circ} \mathrm{C}$. Another part was kept for $10 \mathrm{~min}$ at $37^{\circ} \mathrm{C}$, then preincubated at $37^{\circ} \mathrm{C}$ for $5 \mathrm{~min}$ with $5 \mu \mathrm{g} / \mathrm{ml}$ cytochalasin B (Sigma) to ensure total degranulation, prior to stimulated with $10^{-6} \mathrm{M} N$-formyl methionyl-leucylphenylalanine (fMLP; Sigma) for $10 \mathrm{~min}$. In other experiments, PMN were preincubated for $15 \mathrm{~min}$ with LPS + IL-15, then stimulated with IL-12 for $10 \mathrm{~min}$ at $37^{\circ} \mathrm{C}$. Cell-free supernatants were collected and the cell pellets were sonicated for 30 s to measure cell-associated IFN $\gamma$. Supernatants and cell pellets were stored at $-70^{\circ} \mathrm{C}$ until IFN $\gamma$ assay.

\section{Western Blot Analysis}

Total homogenates of LPS + IL-12-treated and untreated PMN or recombinant human IFN $\gamma$ (rh IFN $\gamma$, R\&D) were added to $2 \times$ Laemmli sample buffer. Proteins were resolved by sodium dodecyl sulfate$10 \%$ polyacrylamide gel electrophoresis (SDSPAGE). Proteins were immunoblotted after transfer to nitrocellulose membranes (Bio-Rad Laboratories, Hercules, CA, USA). Nonspecific sites were blocked 
by incubation for $1 \mathrm{~h}$ in $5 \%$ nonfat dry milk, and the membranes were then probed with a mixture (1:500) of a monoclonal anti-IFN $\gamma$ antibody and then a horseradish-peroxide-labelled goat anti-mouse antibody (1:5000). The immunoblots were developed with an enhanced chemiluminescence method (Amersham, Pharmacia Biotech), following the manufacturer's instructions.

\section{IFN $\gamma$ mRNA Expression}

Highly purified PMN $\left(7 \times 10^{7}\right)$ were incubated for $1 \mathrm{~h}$ in culture medium with LPS (100 ng/ml), IL-12 $(10 \mathrm{ng} / \mathrm{ml})$ and IL-15 $(20 \mathrm{ng} / \mathrm{ml})$. In some experiments, PMN were preincubated for $15 \mathrm{~min}$ with $5 \mu \mathrm{g} / \mathrm{ml}$ actinomycin D (Sigma) to block transcription. Total cellular RNA was isolated with RNA-B ${ }^{\mathbb{R}}$ (Bioprobe systems, Montreuil-sous-Bois, France) according to the manufacturer's instructions. Briefly, cells were lysed in guanidium thiocyanate and RNA was extracted with chloroform then precipitated with isopropanol and washed with $75 \%$ ethanol. The precipitate was solubilized in water and the RNA concentration was determined spectrophotometrically at $260 \mathrm{~nm}$. An amount of $1 \mu \mathrm{g}$ of total RNA was analyzed by electrophoresis on $1 \%$ agaroseformaldehyde gel to check RNA purity and integrity. A measure of $1 \mu \mathrm{g}$ of total RNA was reverse transcribed in a thermocycler (Uno II, Biometra, Voisins le Bretonneux, France) $1 \mathrm{~h}$ at $42^{\circ} \mathrm{C}$ with superscript II reverse transcriptase (Invitrogen), $20 \mathrm{mM}$ of each desoxyribonucleoside triphosphate (dNTP) and $50 \mathrm{U}$ random hexanucleotides primers (Invitrogen). Specific amplifications of IFN $\gamma$ and $\beta$ actin as a housekeeping gene, were performed in a final volume of $25 \mu \mathrm{l}$ containing $\mathrm{MgCl}_{2} 0.5 \mu \mathrm{M}$ for IFN $\gamma$ and $1 \mu \mathrm{M}$ for $\beta$-actin; $200 \mu \mathrm{M}$ of each dNTP; $12 \mathrm{pmol}$ of each specific oligonucleotide primer pair. The sequence of primer pairs used for amplification of complementary DNAs (cDNAs) is as follows:

\section{IFN $\gamma: \quad 5^{\prime}$ CGA GAT GAC TTC GAA AAG CTG ACT 5'CCT TTT TCG CTT CCC TGT TTT A \\ $\beta$-Actin: $\quad 5^{\prime}$ GGA CTT CGA GCA AGA GAT GG 5'AGC ACT GTG TTG GCG TAC AG}

The mixture was heated at $94^{\circ} \mathrm{C}$ for $5 \mathrm{~min}$, then 2.5 U Taq Polymerase (Roche Diagnostics, Meylan, France) were added. polymerase chain reaction (PCR) was performed as follows: denaturation, $94^{\circ} \mathrm{C}$ for $30 \mathrm{~s}$; annealing, $30 \mathrm{~s}$ at $55^{\circ} \mathrm{C}$ for IFN $\gamma$ and $60^{\circ} \mathrm{C}$ for $\beta$-actin; extension, $72^{\circ} \mathrm{C}$ for $40 \mathrm{~s}$. Amplification was stopped after 35 and 30 cycles for IFN $\gamma$ and $\beta$-actin respectively. The expected PCR products of 130 and $234 \mathrm{bp}$ for IFN $\gamma$ and $\beta$-actin, respectively, were detected by electrophoresis in $2 \%$ agarose containing ethidium bromide, along with molecular weight standards, positive and negative controls of PCR. The specificity for IFN $\gamma$ of the amplified sequence was checked using the restriction enzymes
Fnu4HI (Ozyme Biolabs, Saint Quentin en Yvelines, France). Signal intensity was quantified under ultraviolet light with charge-coupled device (CCD) camera using an image analyser (Gel-Analyst, Iconix, Santa Monica, CA, USA) and the expression of IFN $\gamma$ mRNA was expressed as the ratio of the $\beta$-actin gene.

\section{Biological Activity of PMN-Derived IFN $\gamma$}

The biological activity of PMN-derived IFN $\gamma$ was tested on two different cell type targets. In the first autocrine model, IFN $\gamma$ was tested by its capacity to induce TNF $\alpha$ production by LPS-stimulated PMN. ${ }^{16}$ In the second model, IFN $\gamma$ bioactivity was tested by its ability to induce IL-10 production by LPSstimulated PBMC. ${ }^{20,21}$ PMN $\left(10^{7} / \mathrm{ml}\right)$ or PBMC $\left(0.5 \times 10^{6} / \mathrm{ml}\right)$ were cultured with $100 \mathrm{ng} / \mathrm{ml}$ LPS, with or without IFN $\gamma$-containing PMN culture supernatant from previous experiments. Recombinant human IFN $\gamma(\mathrm{rhIFN} \gamma 250 \mathrm{IU} / \mathrm{ml}$ ) was used as positive control. Cells were cultured in the presence or absence of anti-IFN $\gamma$-neutralizing antibody $(1 \mu \mathrm{g} /$ $\mathrm{ml}, \mathrm{R} \& \mathrm{D})$. After $24 \mathrm{~h}$ of culture at $37^{\circ} \mathrm{C}$ with $5 \% \mathrm{CO}_{2}$, cell-free supernatants were stored at $-70^{\circ} \mathrm{Cuntil} \mathrm{TNF} \alpha$ or IL-10 assay.

\section{Cytokine Assays in Cell-Free Supernatants}

IFN $\gamma$, TNF $\alpha$ and IL-10 were quantified by using enzyme-linked immunosorbent assays (ELISA) (R\&D Systems) with respective detection limits of 8,5 and $5 \mathrm{pg} / \mathrm{ml}$.

\section{Statistical Analysis}

Results are expressed as means \pm s.e.m. The various conditions of stimulation were compared by using ANOVA, followed by multiple comparison of means with Fisher's least-significance procedure. Paired comparisons were based on Wilcoxon's paired test. $P$-values $<0.05$ were considered statistically significant.

\section{Results}

\section{IL-12-Induced IFN $\gamma$ Production by PMN}

After $24 \mathrm{~h}$ of culture, IFN $\gamma$ was not detected in the supernatants of unstimulated PMN or of PMN stimulated with LPS, TNF $\alpha$, GM-CSF, IL-2, IL-15 or IL-18 alone (data not shown). By contrast, as shown in Figure 1, IL-12 alone stimulated IFN $\gamma$ production, in a concentration-dependent manner, reaching a plateau after $50 \mathrm{ng} / \mathrm{ml}$. LPS further enhanced IFN $\gamma$ release induced by IL-12. As shown in Figure 2, IFN $\gamma$ release was also enhanced by IL-2, IL-15 and IL-18, the IL-12 + IL-15 combination being most synergistic. LPS further enhanced the effect of IL-2. 


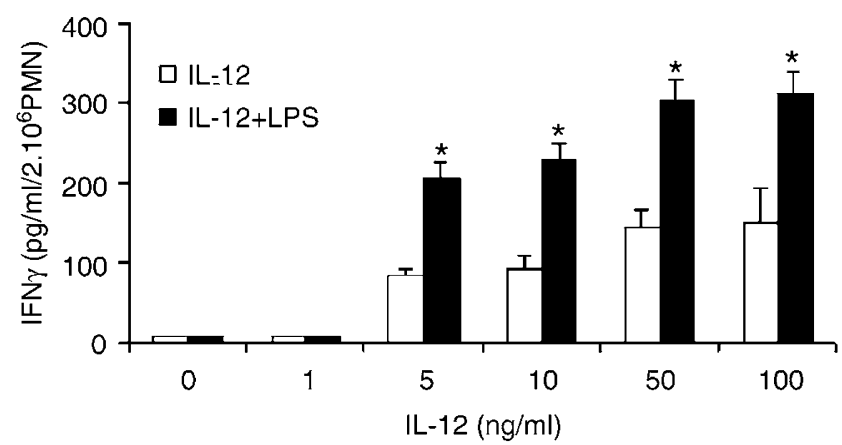

Figure 1 Concentration-response effect of IL-12 on IFN $\gamma$ production by PMN. PMN $\left(2 \times 10^{6} / \mathrm{ml}\right)$ were incubated for $24 \mathrm{~h}$ with increasing concentrations of IL-12, either alone or with LPS ( $100 \mathrm{ng} / \mathrm{ml})$. After $24 \mathrm{~h}$, IFN $\gamma$ was assayed by ELISA in cell-free supernatants. Results are means \pm s.e.m. of three independent experiments. ${ }^{*} P<0.05$ vs cells incubated with IL-12 alone.

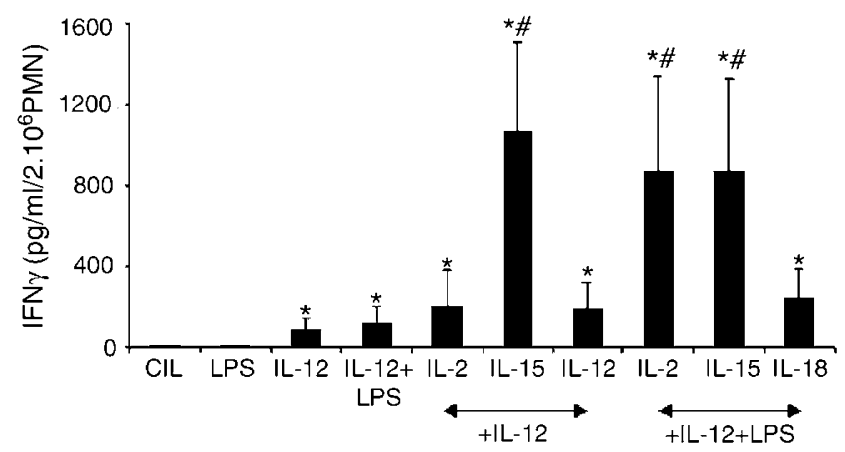

Figure 2 Comparative effects of IL-2, IL-15 and IL-18 on IL-12induced IFN $\gamma$ production by PMN. PMN $\left(2 \times 10^{6} / \mathrm{ml}\right)$ were incubated for $24 \mathrm{~h}$ with various stimuli or in complete medium alone (CTL). IFN $\gamma$ was assayed by ELISA in cell-free supernatants. Results are means \pm s.e.m. of 10 independent experiments. ${ }^{*} P<0.05$ vs LPS or control. $\# P<0.05$ vs IL-12 alone.

Time course study of IFN $\gamma$ release by PMN showed that IFN $\gamma$ was similarly detectable as soon as $2 \mathrm{~h}$ of culture upon stimulation with IL-12 alone or associated with LPS and IL-15 (Table 1). These IFN $\gamma$ amounts reached a plateau by $24 \mathrm{~h}$, and gradually accumulated for up to $48 \mathrm{~h}$ of culture (Table 1).

The central role of IL-12 in IFN $\gamma$ production by PMN was confirmed by single-cell ELISpot assay. Indeed, as shown in Figure 3, the number of spots was optimal using the various associations of IL-12, IL-15, IL-18 and LPS. Positive control cells consisted of autologous PBMC cultured in similar conditions; as expected, IL-12 combined with IL-15 or IL-2 was also the most potent stimulus for IFN $\gamma$ release by PBMC (Figure 3).

\section{Regulation of IFN $\gamma$ Production by Stimulated PMN}

To investigate the mechanism of PMN IFN $\gamma$ release during 24-h culture, cells were preincubated with CHX prior to optimal stimulation (LPS +
Table 1 Time course of IFN $\gamma$ release by PMN (pg/ml/ $2 \times 10^{6} \mathrm{PMN}$ )

\begin{tabular}{ccc}
\hline Duration of stimulation $(h)$ & $I L-12$ & $L P S+I L-12+I L-15$ \\
\hline 2 & $10 \pm 7$ & $17 \pm 9$ \\
6 & $39 \pm 14$ & $187 \pm 62$ \\
12 & $95 \pm 36$ & $535 \pm 181$ \\
24 & $127 \pm 49$ & $872 \pm 423$ \\
48 & $148 \pm 38$ & $1005 \pm 340$ \\
\hline
\end{tabular}

Results are expressed as the means \pm s.e.m. of three experiments.

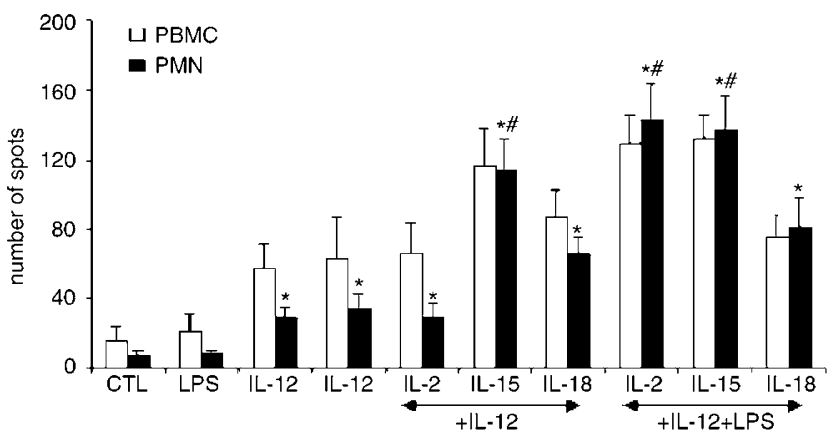

Figure 3 IFN $\gamma$ release by individual PMN in various conditions of stimulation. IFN $\gamma$-secreting cells were visualized by ELISpot in three independent experiments. Autologous PBMC served as positive controls. Cells were stimulated with the indicated agonists. Triplicates were measured in each case and mean$\mathrm{s} \pm$ s.e.m. were calculated. ${ }^{*} P<0.05$ vs resting cells. $\# P<0.05$ vs IL-12 alone.

Table 2 Effect of CHX on stimulus-induced IFN $\gamma$ secretion by PMN

\begin{tabular}{lcc}
\hline & $\begin{array}{l}\text { Without CHX } \\
\text { pretreatment }\end{array}$ & $\begin{array}{l}\text { With } \text { CHX } \\
\text { pretreatment }\end{array}$ \\
\hline Control PMN & $8 \pm 5$ & $8 \pm 4$ \\
LPS+IL-12+IL-15 & $872 \pm 423$ & $10 \pm 5^{*}$ \\
\hline
\end{tabular}

PMN $\left(2 \times 10^{6} / \mathrm{ml}\right)$ were preincubated with or without CHX and then stimulated for $24 \mathrm{~h}$ at $37^{\circ} \mathrm{C}$ in the presence of LPS+IL-12+IL-15 or in medium alone. IFN $\gamma$ was assayed in the cell-free supernatants. Results are expressed as the means \pm s.e.m. of three experiments. ${ }^{*} P<0.05$ as compared with cells incubated without CHX pretreatment.

IL-12 + IL-15), in order to block protein synthesis. As shown in Table 2, the weak IFN $\gamma$ release by unstimulated PMN was not affected by CHX pretreatment. In contrast, after LPS + IL-12 + IL-15 stimulation, IFN $\gamma$ release was significantly reduced by CHX pretreatment as compared with untreated cells, confirming the ability of PMN to synthesize IFN $\gamma$ de novo upon stimulation.

The regulation of PMN IFN $\gamma$ production was also studied at the mRNA level. As shown in Figure 4, IFN $\gamma$ mRNA was low after $1 \mathrm{~h}$ in control PMN, whereas LPS + IL-12 + IL-15-stimultated PMN 


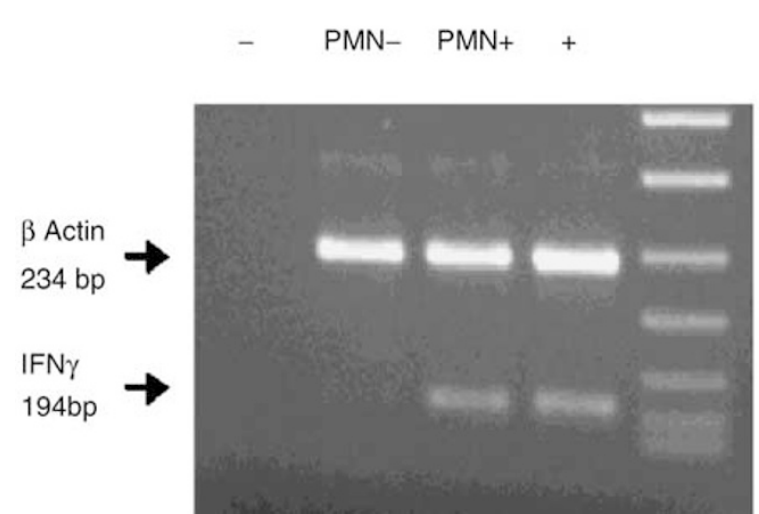

MW

404

320

242

190

147

124

Figure 4 RT-PCR analysis of IFN $\gamma$ mRNA expression in PMN. Total RNA was extracted from resting (PMN-) and activated PMN (LPS + IL-12 + IL-15) (PMN +). After reverse transcription, PCR was carried out with specific pairs of primers designed for IFN $\gamma$ and $\beta$-actin. Total lung tissue served as positive control $(+)$. The figure indicates the size of amplification products relative to molecular weight standards run in parallel (MW) and the negative control (-) (PCR buffer without cDNA).

Table 3 Effect of degranulating agents on IFN $\gamma$ secretion by human PMN

\begin{tabular}{lcr}
\hline & Cell-associated & Secreted \\
\hline Control $4{ }^{\circ} \mathrm{C}$ & $33 \pm 17$ & $8 \pm 5$ \\
Control $37^{\circ} \mathrm{C}$ & $19 \pm 4$ & $11 \pm 9$ \\
Cyt B+fMLP & $8 \pm 5^{*}$ & $18 \pm 7$ \\
LPS+IL-12+IL-15 & $10 \pm 4^{*}$ & $20 \pm 7$ \\
\hline
\end{tabular}

Secreted IFN $\gamma$ was measured in cell lysates and supernatants of of PMN $\left(10^{7} / \mathrm{ml}\right)$ maintained at $4^{\circ} \mathrm{C}$ or incubated for $15 \mathrm{~min}$ at $37^{\circ} \mathrm{C}$ with or without inducers of degranulation. Results are expressed as the mean \pm s.e.m. of six independent experiments. ${ }^{*} P<0.05$ vs control $\mathrm{PMN}$ at $4^{\circ} \mathrm{C}$.

exhibited a $450 \%$ increase in IFN $\gamma$ mRNA expression measured by densitometric analysis and expressed as a ratio to $\beta$-actin.

Taken together, these data suggest that regulation of the PMN IFN $\gamma$ gene, in optimal conditions of stimulation, might take place, at least in part, at the transcriptional level.

\section{Human PMN Contain a Small Intracellular Pool of IFN $\gamma$}

Two complementary techniques were used to determine whether IFN $\gamma$ is constitutively present in resting human blood PMN, namely degranulation, and Western blotting. Degranulation experiments were conducted with purified PMN maintained at $4^{\circ} \mathrm{C}$, and with or without inducers of degranulation, for $15 \mathrm{~min}$ at $37^{\circ} \mathrm{C}$. Released and cell-associated IFN $\gamma$ were measured separately. As shown in Table 3, the amount of cell-associated IFN $\gamma$ was $33 \pm 17 \mathrm{pg} / 10^{7}$ $\mathrm{PMN}$ in basal conditions. Incubation at $37^{\circ} \mathrm{C}$ in both

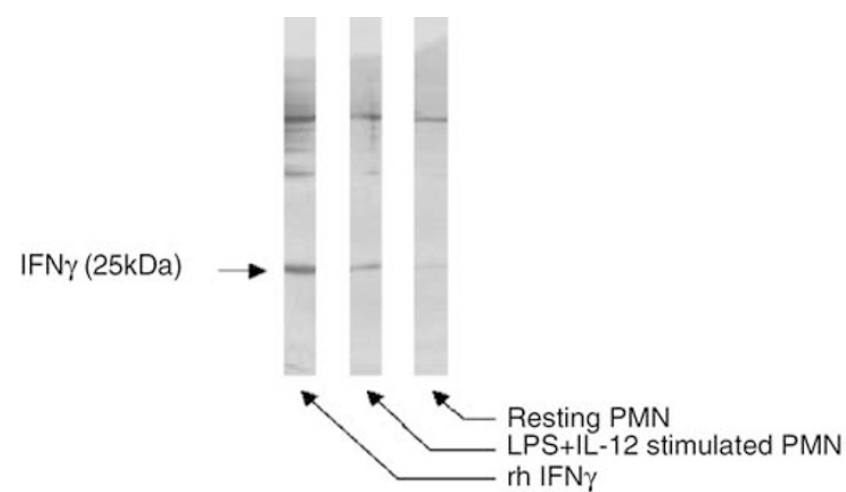

Figure 5 Western blot analysis of IFN $\gamma$ expression by human PMN. Total homogenates of resting purified PMN or LPS + IL-12treated PMN were added to $2 \times$ Laemmli sample buffer, and proteins were resolved by SDS-PAGE. Proteins were immunoblotted after transfer to nitrocellulose membranes. Recombinant human IFN $\gamma($ rh IFN $\gamma$ ) served as positive control.

degranulating conditions led to a reduction in cellassociated IFN $\gamma$, with a parallel increase in extracellular IFN $\gamma$. These results suggested that a small pre-existing pool of IFN $\gamma$ was rapidly released. Western blot analysis of total PMN homogenates both stimulated and unstimulated revealed a clear $25-\mathrm{kDa}$ band migrating at the same level as recombinant human IFN $\gamma$ (Figure 5).

\section{IFN $\gamma$ Bioactivity}

The autocrine and paracrine regulation loops of cytokine production are of major importance. We chose to test the PMN-derived IFN $\gamma$ bioactivity on two different models, using PMN or PBMC as target cells. As IFN $\gamma$ is necessary to induce TNF $\alpha$ production by PMN, we investigated in the first model the ability of culture supernatants of LPS + IL-12 + IL15 -stimulated PMN to induce TNF $\alpha$ release by PMN treated with LPS alone. We selected three healthy donors, whose PMN culture supernatants contained 1.4, 1.5 and $1.6 \mathrm{ng} / \mathrm{ml} \mathrm{IFN} \gamma$, as measured by ELISA. In the second model, we investigated the ability of these same three supernatants to potentiate IL-10 release by LPS-stimulated PBMC. As shown in Figure $6 \mathrm{a}$ and $\mathrm{b}, \operatorname{rhIFN} \gamma(1.5 \mathrm{ng} / \mathrm{ml})$ and all three PMN culture supernatants stimulated TNF $\alpha$ release by PMN and IL-10 release by PBMC as compared to LPS alone. Neutralizing antibodies against IFN $\gamma$ partially inhibited both cytokine productions, suggesting that $\mathrm{PMN}$-derived IFN $\gamma$ was biologically active.

\section{Discussion}

Our results suggest that a small pre-existing pool of IFN $\gamma$ is present in resting PMN, and that it is rapidly released in degranulating conditions. IFN $\gamma$ was also synthesized after PMN stimulation by various 

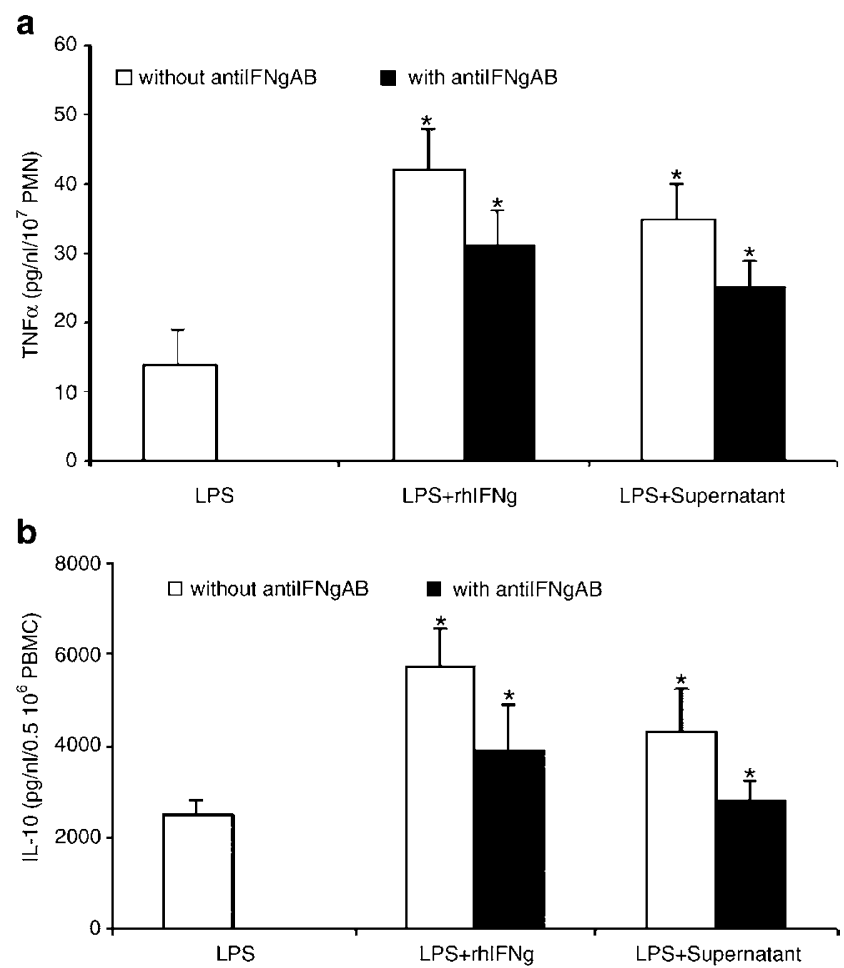

Figure 6 Biological activity of neutrophil-derived IFN $\gamma$. PMN $\left(10^{7} / \mathrm{ml}\right)$ (a) or PBMC $\left(0.5 \times 10^{6} / \mathrm{ml}\right)$ (b) were cultured in the presence of $100 \mathrm{ng} / \mathrm{ml}$ LPS, with or without PMN culture supernatants containing IFN $\gamma$ (obtained in previous experiments). Recombinant human IFN $\gamma$ ( $\mathrm{rhIFN} \gamma 250 \mathrm{IU} / \mathrm{ml}$ ) was used as a positive control. Each culture was done in the presence or absence of anti-IFN $\gamma$ neutralizing antibody $(1 \mu \mathrm{g} / \mathrm{ml})$. Cell-free supernatants were harvested after $24 \mathrm{~h}$ of culture at $37^{\circ} \mathrm{C}$ in $5 \%$ $\mathrm{CO}_{2}$, and were stored at $-70^{\circ} \mathrm{C}$ until $\mathrm{TNF} \alpha$ and IL-10 assays. ${ }^{*} P<0.05$ vs LPS.

agonists, the combination of IL-12 and IL-15 being the most efficient. A transcriptional regulation of the IFN $\gamma$ gene in PMN was suggested. PMN-derived IFN $\gamma$ could orient adaptive immune responses, particular at sites of inflammation.

We have developed a three-step isolation procedure to rule out PMN contamination by other cell types, based on Dextran-Radioselectan sedimentation, Ficoll centrifugation, and immunomagnetic depletion of HLA class II-positive cells (particularly monocytes and activated T lymphocytes, which can release IFN $\gamma$ ). As previously described by our group, the purity of the PMN preparations was confirmed by several controls: flow cytometry showed neither CD3 + nor CD56 + cells ( $\mathrm{T}$ cells and NK cells, respectively); ${ }^{4}$ nonspecific esterase staining always evidenced less than $0.1 \%$ of monocytes $;{ }^{17}$ neither IL-10 or IL-13 protein or mRNA could be induced..$^{18}$ Eosinophils were not involved in the observed IFN $\gamma$ release, as these cells require CD28 ligation to release IFN $\gamma{ }^{12}$

Western blot analysis revealed a band corresponding to IFN $\gamma$ in resting PMN. Immunocytochemistry was also performed but did not allow to visualize

significant level of intracellular IFN $\gamma$ in resting cells (data not shown). The existence of a small intracellular store of IFN $\gamma$ in PMN was confirmed by IFN $\gamma$ release into the extracellular medium after $15 \mathrm{~min}$ of incubation with degranulating agents. Although this IFN $\gamma$ pool was small compared with the amount of synthesized after $24 \mathrm{~h}$ of culture, it may have an important role, as rapid IFN $\gamma$ secretion by the numerous PMN infiltrating inflammatory tissues could orient the local immune response at an early stage. Other preformed cytokines released rapidly by PMN after exposure to degranulating agents include HGF, OSM and VEGF. ${ }^{3,4,22}$ Our results are in keeping with previous flow cytometry-based studies showing that IFN $\gamma$ is barely detectable in unstimulated PMN from human blood, ${ }^{13}$ and from normal mouse spleen and lung. ${ }^{14,15}$

Our findings also show that PMN can synthesize significant amounts of $\mathrm{IFN} \gamma$ as soon as $2 \mathrm{~h}$ of appropriate ex vivo stimulation. We used two complementary techniques to visualize and quantify newly produced IFN $\gamma$. First, IFN $\gamma$ was detected by ELISA in PMN culture supernatants after exposure to appropriate stimuli. Second, the number of ELISPOT spots increased markedly after stimulation. Several stimuli classically described to upregulate cytokine production by PMN, such as LPS, TNF $\alpha$ and GM-CSF ${ }^{1}$ were ineffective when used alone. Similar findings were obtained by Keel et $a^{23}$ with LPS alone, whereas Yeaman et $a l^{13}$ detected low concentrations of IFN $\gamma$ after $\mathrm{TNF} \alpha$ or LPS stimulation; this discrepancy could be related to differences in cell preparation and purification.

IL-12 was the most efficient stimulus after $24 \mathrm{~h}$ of culture, upregulating IFN $\gamma$ production in a time- and concentration-dependent manner. Interestingly, IL12 was synergistic with IL-2, IL-15 or IL-18; in particular, IL-15 potentiated IL-12-induced IFN $\gamma$ release by a factor of 10 . These four cytokines have already been shown to influence other PMN functions. ${ }^{24}$ IL-12 is chemotactic for PMN, and also activates IL-8 and TNF $\alpha$ synthesis. ${ }^{25,16}$ IL-15 plays a role in maintaining inflammatory processes, by increasing phagocytosis, inducing cytoskeleton changes, delaying apoptosis and increasing chemokine production. ${ }^{26-28}$ IL-2 shares with IL-15 many biological effects on $\mathrm{PMN} ;{ }^{27}$ the underlying mechanisms include association of lyn protein tyrosine kinase with IL-2R $\beta$, and direct binding of MAPK/ ERK1 to lyn and a proteolytically processed fulllength STAT5 protein. ${ }^{29,30}$ IL-18 can activate PMN, by priming NADPH-oxidase, increasing $\beta 2$ integrin expression, activating p38-MAPK, and driving the production of leukotriene B4. ${ }^{31,32}$ IL-12 in combination with IL-18 or IL-15 has been reported to increase synergistically IFN $\gamma$ production by various cells. For example, IL-12 and IL-15 synergize to induce murine NK cell IFN $\gamma$ release. ${ }^{8}$ IL-12 and IL18 also exhibit marked synergism for IFN $\gamma$ induction 
by $\mathrm{T}$ cells, ${ }^{9}$ macrophages, ${ }^{10}$ dendritic cells and $\mathrm{B}$ cells; ${ }^{11}$ the STAT4 and p38 MAPK pathways are both involved in these effect. ${ }^{33}$ Our study demonstrates for the first time that, upon combined stimulation with IL-12, IL-15, IL-18 or IL-2, human PMN can also participate in IFN $\gamma$ production. Our in vitro findings confirm the results of two recent in vivo studies $^{14,15}$ showing the involvement of lung- and spleen-infiltrating $\mathrm{PMN}$ in IFN $\gamma$ production in two mouse models of infection (Nocardia asteroides and Salmonella typhimurium).

To elucidate the mechanism of IFN $\gamma$ release by PMN, we pretreated cells with CHX prior to optimal stimulation. IFN $\gamma$ release fell markedly, confirming that de novo protein synthesis was the main source of PMN-derived IFN $\gamma$. Moreover, specific mRNA content correlated with IFN $\gamma$ protein release. RTPCR studies showed that IFN $\gamma$ mRNA expression by stimulated PMN was largely increased as early as $1 \mathrm{~h}$. A similar regulatory mechanism has already been demonstrated by us and others for several cytokines such as IL-8 $8^{1,5}$ or OSM. ${ }^{17}$

The IFN $\gamma$ produced by PMN was biologically active as tested by two different models. Indeed, stimulated PMN supernatants upregulated TNF $\alpha$ production by LPS-stimulated PMN, which is known to be IFN $\gamma$-dependent, ${ }^{1,5}$ and IL-10 production by LPS-stimulated PBMC. ${ }^{20,21}$ Anti-IFN $\gamma$ antibodies partly inhibited this $\mathrm{TNF} \alpha$ or IL-10 production since other mediators are involved in their synthesis. We chose these two models because they represent some of the major biological and functional implications for these results. The ability of PMN to produce the powerful activating cytokine IFN $\gamma$ points to a new role for these cells during innate immune responses. Specifically, they suggest the existence of a new autocrine modulation loop, in which IFN $\gamma$-derived PMN might play a key role. Indeed, at sites of local inflammation, IFN $\gamma$-derived PMN could regulate several neutrophil functions, such as the oxidative burst, migration, apoptosis and cytokine production as recently reviewed. ${ }^{1,33-36}$ Moreover, PMN-derived IFN $\gamma$ and IL-12 could influence the adaptive immune response towards T-helper polarization, both locally and in the systemic circulation. ${ }^{37}$ This would offers a new explanation for the crucial importance of IFN $\gamma$ in antimicrobial immunity. Inherited disorders of IFN $\gamma$ - and IL-12-mediated immunity described in recent years (defects in IFN $\gamma$ receptors 1 and 2, STAT1, IL-12 $\beta$ receptor 1 and IL-12p40) predispose patients to severe infections by intracellular pathogens, and especially mycobacteria. ${ }^{38,39}$ Very recently, neutralizing anti-IFN $\gamma$ autoantibodies were found in a patient with severe Mycobacteria cheloneae infection. ${ }^{40}$ IFN $\gamma$ therapy has a beneficial effect on phagocyte functions both in vivo and ex vivo. IFN $\gamma$ prophylaxis improved the PMN oxidative burst in two patients with chronic granulomatous disease, by partially correcting the abnormal splicing of NADPH-oxidase CYBB gene transcripts. ${ }^{41,42}$ Also, inhaled IFN $\gamma$ restored normal pulmonary immune status in patients with severe trauma and immune paralysis. ${ }^{43}$ Finally, our data may explain the intriguing role of PMN in antitumor reactions, as reviewed by Di Carlo et $a .^{44}$ Intratumoral PMN-derived IFN $\gamma$ might be a key mediator in the cross talk between tumor cells, phagocytes and T cells, thereby orchestrating tumor rejection, particularly after recombinant IL-12 therapy.

In conclusion, our in vitro findings confirm recently published observations, in particular in mouse models of infection, by demonstrating that human PMN can secrete IFN $\gamma$ by a two-step mechanism. First, release of a small preformed stock of IFN $\gamma$ can be triggered by appropriate stimuli, and this is followed by de novo IFN $\gamma$ synthesis. These stimuli include IL-12, both alone and combined with IL-2, IL-15 or IL-18. The potential new autocrine and paracrine regulatory loop identified in this study points to a novel pathway for cross talk between PMN and other immune cells, particularly at local sites of inflammation. PMN IFN $\gamma$ release may play a pivotal role, not only during early innate immune responses and antitumoral reactions, but also during the regulation and orientation of adaptive immunity.

\section{Acknowledgement}

We are grateful to $\mathrm{V}$ Leçon-Malas for expert technical assistance.

\section{Duality of Interest}

The authors declare no duality of interest.

\section{References}

1 Cassatella MA. Neutrophil-derived proteins: selling cytokines by the pound. Adv Immunol 1999;73: 369-509.

2 Ethuin F, Chollet-Martin S. Cytokine production by neutrophils. In: Gabrilovich DI (ed). The Neutrophils: New Outlook for Old Cells, 2nd edn. Imperial College Press, 2004, in press.

3 Grenier A, Chollet-Martin S, Crestani B, et al. Presence of a mobilizable intracellular pool of hepatocyte growth factor in human polymorphonuclear neutrophils. Blood 2002;99:2997-3004.

4 Grenier A, Combaux D, Chastre J, et al. Oncostatin M production by blood and alveolar neutrophils during acute lung injury. Lab Invest 2001;81:133-141.

5 Taïeb J, Delarche C, Ethuin F, et al. Ethanol-induced inhibition of cytokine release and protein degranulation in human neutrophils. J Leukoc Biol 2002;72: 1142-1147.

6 Scapini P, Nardelli B, Nadali G, et al. G-CSF-stimulated neutrophils are a prominent source of functional BLyS. J Exp Med 2003;197:297-302. 
7 Brandt E, Gaetane W, Younes AB, et al. IL-4 production by human polymorphonuclear neutrophils. J Leukoc Biol 2000;68:125-130.

8 Fehniger TA, Yu H, Cooper MA, et al. Cutting Edge: IL-15 costimulates the generalized Schwartzman reaction and innate immune IFN $\gamma$ production in vivo. J Immunol 2000;164:1643-1647.

9 Ariel A, Novick D, Rubinstein M, et al. IL-12 and IL-18 induce MAP kinase-dependent adhesion of T cells to extracellular matrix components. J Leukoc Biol 2002; 72:192-198.

10 Munder M, Mallo M, Eichmann K, et al. Murine macrophages secrete interferon $\gamma$ upon combined stimulation with interleukin (IL)-12 an IL-18: a novel pathway of autocrine macrophage activation. J Exp Med 1998;187:2103-2108.

11 Yoshimoto T, Okamura O, Tagawa Y-I, et al. Interleukin-18 together with interleukin-12 inhibits $\operatorname{IgE}$ production by induction of interferon- $\gamma$ production from activated B cells. Proc Natl Acad Sci USA 1997;94:3948-3957.

12 Woerly G, Roger N, Loiseau S, et al. Expression of CD28 and CD86 by human eosinophils and role in the secretion of type 1 cytokines (interleukin 2 and interferon $\gamma$ ): inhibition by immunoglobulin A complexes. J Exp Med 1999;16:487-495.

13 Yeaman GR, Collins JE, Currie JK, et al. IFN $\gamma$ is produced by polymorphonuclear neutrophils in human uterine endometrium and by cultured peripheral blood polymorphonuclear neutrophils. J Immunol 1998;160:5145-5153.

14 Kirby AC, Yrlid U, Wick MJ. The innate immune response differs in primary and secondary salmonella infection. J Immunol 2002;169:4450-4459.

15 Ellis TN, Beaman BL. Murine polymorphonuclear neutrophils produce interferon- $\gamma$ in response to pulmonary infection with Nocardia asteroides. J Leukoc Biol 2002;72:373-381.

16 Ethuin F, Delarche C, Benslama S, et al. Interleukin-12 increases interleukin-8 production and release by human polymorphonuclear neutrophils. J Leukoc Biol 2001;70:439-446.

17 Grenier A, Dehoux M, Boutten A, et al. Oncostatin M production and regulation by human polymorphonuclear neutrophils. Bloaod 1999;93:1413-1421.

18 Reglier H, Arce-Vicioso M, Fay M, et al. Lack of IL-10 and IL-13 production by human polymorphonuclear neutrophils. Cytokine 1998;10:192-198.

19 Chen BJ, Cui X, Liu C, et al. Prevention of graft-versushost disease while preserving graft-versus-leukemia effect after selective depletion of host-reactive T cells by photodynamic cell purging process. Blood 2002;99:3083-3088.

20 Windhagen A, Anderson DE, Carrizosa A, et al. IL-12 induces human T cells secreting IL-10 with IFN-gamma. J Immunol 1996;157:1127-1131.

21 Mühl H, Pfeilschifter J. Anti-inflammatory properties of pro-inflammatory interferon- $\gamma$. Int Immunopharmacol 2003;3:1247-1255.

22 Gaudry M, Bregerie O, Andrieu V, et al. Intracellular pool of vascular endothelial growth factor in human neutrophils. Blood 1997;90: 4153-4161.

23 Keel M, Ungethüm U, Steckholzer E, et al. Interleukin10 counterregulates proinflammatory cytokine-induced inhibition of neutrophil apoptosis during severe sepsis. Blood 1997;90:3356-3363.
24 Trinchieri G. Interleukin-12 and the regulation of innate resistance and adaptive immunity. Nat Rev 2003;3:133-146.

25 Al-Mohanna F, Saleh S, Parhar RS, et al. IL-12dependent nuclear factor-kappaB activation leads to de novo synthesis and release of IL-8 and TNFalpha in human neutrophils. J Leukoc Biol 2002;72: 995-1002.

26 Fehniger TA, Caligiuri MA. Interleukin 15: biology and relevance to human disease. Blood 2001;97:14-32.

27 Cassatella MA, McDonald PP. Interleukin-15 and its impact on neutrophil function. Curr Opin Hematol 2000;7:174-177.

28 Girard D, Paquet M-E, Paquin R, et al. Differential effects of interleukin-15 (IL-15) and IL-2 on human neutrophils: modulation of phagocytosis, cytoskeleton rearrangement, gene expression, and apoptosis by IL-15. Blood 1996;8:3176-3184.

29 Epling-Burnette PK, Garcia R, Bai F, et al. Carboxyterminal truncated STAT5 is induced by interleukin-2 and GM-CSF in human neutrophils. Cell Immunol 2002;217:1-11.

30 Wei S, Liu LH, Epling-Burnette PK, et al. IL-2 induces the association of IL-2Rbeta, lyn, and MAP kinase ERK-1 in human neutrophils. Immunobiology 2000; 202:363-382.

31 Cannetti CA, Leung BP, Culshauw S, et al. IL-18 enhances collagen-induced arthritis by recruiting neutrophils via TNF-alpha and leukotriene B4. J Immunol 2003;171:1009-1015.

32 Wyman TH, Dinarello CA, Banerjee A, et al. Physiological levels of interleukin-18 stimulate multiple neutrophil functions through p38 MAP kinase activation. J Leukoc Biol 2002;72:401-409.

33 Zhang P, Quinton LJ, Bagby GJ, et al. Interferon- $\gamma$ enhances the pulmonary CXC chemokine response to intratracheal lipopolysaccharide challenge. J Infect Dis 2003;187:62-69.

34 Lieser MJ, Kozol RA, Tennenberg SD. Interferongamma primes neutrophil-mediated gastric surface cell cytotoxicity. Am J Physiol Gastrointest Liver Physiol 1995;268:843-848.

35 McLoughlin RM, Witowski J, Robson RL, et al. Interplay between IFN- $\gamma$ and IL-6 signaling govern neutrophil trafficking and apoptosis during acute inflammation. J Clin Invest 2003;112:598-607.

36 Ellis TN, Beaman BL. Interferon-gamma activation of polymorphonuclear neutrophil functions. Immunology 2004;112:2-12.

37 Das G, Sheridan S, Janeway CA. The source of early IFN- $\gamma$ that plays a role in Th1 priming. J Immunol 2001;167:2004-2010.

38 Fieschi C, Casanova J-L. Mini-review: the role of interleukin-12 in human infectious diseases: only a faint signature. Eur J Immunol 2003;33:1461-1464.

39 Dupuis S, Döffinger R, Picard C, et al. Human interferon- $\gamma$-mediated immunity is a genetically controlled continuous trait that determines the outcome of mycobacterial invasion. Immunol Rev 2000;178: 129-137.

40 Höflich C, Sabat R, Rosseau S, et al. Naturally occuring anti-IFN- $\gamma$ auto-antibody and severe infections with Mycobacterium cheloneae and Burkholderia cocovenemans. Blood 2004;103:673-675.

41 Ishibashi F, Mizukami T, Kanegasaki S, et al. Improved superoxide-generating ability by interferon $\gamma$ due to splicing pattern change of transcripts in neutrophils 
from patients with a splice site mutation in CYBB gene. Blood 2001;98:436-441.

42 Condino-Neto A, Newburger PE. Interferon gamma improves splicing efficiency of CYBB gene transcripts in an interferon-responsive variant of chronic granulomatous disease due to splice site consensus region mutation. Blood 2000;95:3548-3554.
43 Nakos G, Malamou-Mitsi VD, Lachana A, et al. Immunoparalysis in patients with severe trauma and the effect of inhaled interferon- $\gamma$. Crit Care Med 2002;30:1488-1494.

44 Di Carlo E, Forni G, Lollini PL, et al. The intriguing role of polymorphonuclear neutrophils in antitumor reactions. Blood 2001;97:339-345. 